\title{
Front Matter: Volume 11594
}

, "Front Matter: Volume 11594," Proc. SPIE 11594, NDE 4.0 and Smart Structures for Industry, Smart Cities, Communication, and Energy, 1159401 (29 April 2021); doi: 10.1117/12.2597519

SPIE. Event: SPIE Smart Structures + Nondestructive Evaluation, 2021, Online Only 


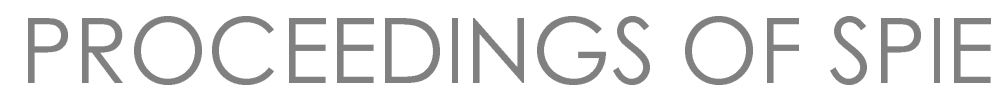

\title{
NDE 4.0 and Smart Structures for Industry, Smart Cities, Communication, and Energy
}

\author{
Norbert G. Meyendorf \\ Saman Farhangdoust \\ Christopher Niezrecki \\ Editors
}

22-26 March 2021

Online Only, United States

Sponsored and Published by

SPIE

Volume 11594 
The papers in this volume were part of the technical conference cited on the cover and title page. Papers were selected and subject to review by the editors and conference program committee. Some conference presentations may not be available for publication. Additional papers and presentation recordings may be available online in the SPIE Digital Library at SPIEDigitalLibrary.org.

The papers reflect the work and thoughts of the authors and are published herein as submitted. The publisher is not responsible for the validity of the information or for any outcomes resulting from reliance thereon.

Please use the following format to cite material from these proceedings:

Author(s), 'Title of Paper," in NDE 4.0 and Smart Structures for Industry, Smart Cities, Communication, and Energy, edited by Norbert G. Meyendorf, Saman Farhangdoust, Christopher Niezrecki, Proc. of SPIE 11594, Seven-digit Article CID Number (DD/MM/YYYY); (DOI URL).

ISSN: 0277-786X

ISSN: 1996-756X (electronic)

ISBN: 9781510640177

ISBN: 9781510640184 (electronic)

Published by

SPIE

P.O. Box 10, Bellingham, Washington 98227-0010 USA

Telephone +1 3606763290 (Pacific Time)

SPIE.org

Copyright @ 2021 Society of Photo-Optical Instrumentation Engineers (SPIE).

Copying of material in this book for internal or personal use, or for the internal or personal use of specific clients, beyond the fair use provisions granted by the U.S. Copyright Law is authorized by SPIE subject to payment of fees. To obtain permission to use and share articles in this volume, visit Copyright Clearance Center at copyright.com. Other copying for republication, resale, advertising or promotion, or any form of systematic or multiple reproduction of any material in this book is prohibited except with permission in writing from the publisher.

Printed in the United States of America by Curran Associates, Inc., under license from SPIE.

Publication of record for individual papers is online in the SPIE Digital Library.

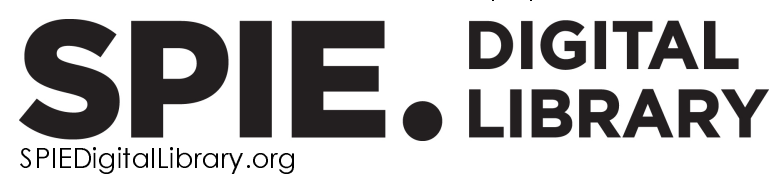

Paper Numbering: A unique citation identifier (CID) number is assigned to each article in the Proceedings of SPIE at the time of publication. Utilization of CIDs allows articles to be fully citable as soon as they are published online, and connects the same identifier to all online and print versions of the publication. SPIE uses a seven-digit CID article numbering system structured as follows:

- The first five digits correspond to the SPIE volume number.

- The last two digits indicate publication order within the volume using a Base 36 numbering system employing both numerals and letters. These two-number sets start with $00,01,02,03,04$, $05,06,07,08,09,0 A, 0 B \ldots$ OZ, followed by 10-1Z, 20-2Z, etc. The CID Number appears on each page of the manuscript. 


\section{Contents}

NDE 4.0: NEXT GENERATION NDE

1159405 NDE 4.0 for in-motion wheel inspection of a high-speed train via a RF energy harvesting module: an autonomous cyber-physical approach toward the smart city [11594-3]

1159409 An advanced methodology for 3D digitization and nondestructive evaluation of monuments [11594-7]

MATERIALS, NDE, AND SENSORS FOR ENERGY SYSTEMS

11594 OF Effects of a cement cap on the bulk properties of cement cores embedded with optical fiber sensor prototypes [11594-13]

11594 OG Regression model for structural health monitoring of a lab scaled bridge [11594-18]

POSTER SESSION

$11594 \mathrm{OH} \quad$ Static performance analysis of a single layer cable net structure [1 1594-14]

$115940 \mathrm{~J} \quad$ Design of intrusion detection systems on the internet of things infrastructure using machine learning algorithms [11594-16]

POST-DEADLINE

11594 OK Probability of detection analysis in multi-hit flaw detection [1 1594-20] 
Proc. of SPIE Vol. 11594 1159401-4 Downloaded From: https://www.spiedigitallibrary.org/conference-proceedings-of-spie on 26 Apr 2023
Terms of Use: https://www.spiedigitallibrary.org/terms-of-use 